\title{
New Teaching Techniques: for acquisition of English language
}

\author{
Velamala Divyajyothi \\ Assistant Professor (Dept. Of English), Aditya Institute of Technology \& Management, Tekkali, Srikakulam \\ Dist.
}

\begin{abstract}
The acquisition of knowledge or skills through study, experience, or being taught is known as learning. Same time, teaching is imparting knowledge or skill. Whether it is telling, conditioning or constructing, a teacher should consider that the student is a product of the system and anticipate that certain teaching methods will result in proper learning. Concerning with English learning, most of the English learners and students, who receive education in their vernacular medium, usually show only a partial involvement in learning English and improve proficiency. Many of them believe that second language acquisition is bit difficult. At the same time, in our environment, English teaching methodologies being practiced currently are not in line with satisfactory results. English teachers who are at the beginning of their career should focus on enhancing their teaching ability and practicing some student-friendly methods to make them show their interest in learning of other language skills. It is the known fact that correspondence between the language structures between the mother tongue and second language is the most important factor in language acquisition. Changing in teaching methods may reduce the correspondence gap between the two languages and tend the students focusing on learning of acquired language. Some methods with simple techniques may facilitate the learner to increase the amount of time spent speaking English. The main objective of these techniques is to make the students or English learners more enthusiastic to acquire the language other than their mother tongue. Linguistic methodologists should endeavour their skill and methodologies in designing new and unconventional or alternative techniques in English teaching patterns.

The purpose of this paper is to discuss the possible innovative transfer-friendly teaching methods that can be followed in classroom.
\end{abstract}

Keywords: teaching techniques, Teaching with simple materials, Vocabulary Activity, Shared Reading, Self Selected Reading Logs

\section{Introduction}

Innovation in its many dimensions is emerging as a leading factor for any society for economic and social growth. Education system is also employing various drivers in terms of innovation to yield improved quality with new ideas. In our mega scale education system, it is a major challenge to cater huge population with relatively limited resources. Rapid advances in educational system assist teachers disseminate information in the view of student-centered teaching. Teachers should strive to update early models of teaching and the managements of educational institutions or organisations put efforts to create acceptable tools of assessing teaching and learning while providing support for new teachers with workshops and semester-long training modules.

Pertaining to English language teaching and learning, Indian students particularly who are speakers of other languages are not focussing fully to acquire English language. Most of them are not provided supportive and productive learning environment. The learning environment should promote independence, interdependence and self-motivation among the students. English teachers should try to focus on Students' needs, backgrounds, perspectives and interests in their teaching programs. The students should be challenged and supported to develop their levels of learning through continuous classroom assessment practices. Students are to be encouraged to connect communities strongly and practice beyond the classroom. Teachers are to be provided with comprehensive resources to help them teach and delivering English language to the students. Such teaching and learning resources assist and self-motivate students who come from a language background other than English. English books and publications with diversified interests may attract students to learn English as an additional language. Such publications help and assist teachers to build their teaching power and make the students expand their learning capacity.

\section{Teaching with simple materials} lesson ideas.

With concrete objectives and simple materials surrounded with us, a teacher can accommodate some 
Vocabulary Activity

Objective: Building Vocabulary

Materials: Flashcards, Crayons, Pencil

Activity: In groups of two the students will make vocabulary flash cards with the vocabulary on one card and a picture representing it on another card. When they are done they will be able to play memory which will help them associate the picture with the word and practice their vocabulary words.

Shared Reading

Objective: Reinforce reading skills

Materials: Picture Book

Activity: Read the story aloud to the students and allow them to join in the reading or reread when they feel comfortable. During the repeated readings attract the students' attention to different vocabulary and punctuation

Self Selected Reading Logs

Objective: To allow the student to choose their own reading and to instill a joy of reading and to keep record and understand where the student's interests lie and where they may need guidance in their reading.

Materials: book of student's choice, notebook

Activity: Allow time for sustained reading in class and have students keep track of titles and authors read. Time can be used for having the students share their preferred reading and recommend them to other students.

\section{Techniques which aids us}

Teaching English to English language learners can be challenging. The following are ideas and techniques to make lessons more interesting and effective.

\section{Repeat and Re-phrase}

The repeat and re-phrase technique is effective in classrooms because a student may know various vocabulary words and now know the ones that the teacher is using. By using this technique the teacher exposes the student to new vocabulary that can be associated with the old to acquire a meaning. The student gets benefitted by both the repetition, as the source of learning new vocabulary, and the use of old vocabulary to form a re-phrased question in order to acquire a new and better understanding of the English language.

This technique can be used during oral instruction given to the class or an individual student. It can also be applied during question and answer time in class, and is optimal for such a use as it provides students with an opportunity to better understand the question and answer it without help. This promotes the level of learning, understanding, and self-confidence in students.

The repeat and re-phrase strategy is used in the classroom to promote, achieve, or ensure, understanding of a given topic, standard, or question. For example: if a student doesn't understand the question "what is the meaning of an adjective?" Then the teacher can respond by either repeating, and/or if understanding is still not reached, re-phrasing the question to promote the student's application of knowledge. The question could be re-phrased as: "What does an adjective do?" This also helps with future questions as the student will better understand the meaning of the posed question.

Additionally, the repeat and re-phrase can be used to question for understanding by re-phrasing a sentence to check if the student properly understood the meaning of a particular word or concept. For example: "The girl avoided the water" - is for used to teach the vocabulary term "avoid."

Questioning for understanding could be phrased as: "If she avoided the water, then she isn't wet." The teacher can ask whether this is correct or not and the students can better understand what the term means and its uses.

\section{Cooperative Groups, Peer Coaching}

This technique optimizes personalized student learning time as each student can get personalized attention even if it is not given by the teacher. This is also helpful when the teacher is not supposes to be the focus of activities and instead can move from table to table and help as needed. It creates a community setting and gets students into helping each other and learning from each other. Cooperative groups work because there are many ways to break students into groups that allow them personally catered lessons on their level.

Placing students in cooperative groups or using peer coaching is especially helpful in an ELL classroom where students are or can be at mixed levels of learning English. When this is the case it is best to place them in groups that are chosen by the teacher in a manner that places higher level students with lower level ones. In this way the higher level student is learning, practicing, and perfecting techniques through 
teaching; and the lower level student is acquiring new knowledge and receiving help from a peer. This can also be used to place higher level students together to work on an assignment while the lower level students stay with the teacher to learn new information. In this way the teacher is able is optimize learning by provide new information to both levels without actually having to make one or the other sit through information that is either below or above their learning level.

The learning outcome of this strategy is that students are able to take in more information at one time while developing relationships and community amongst themselves. Additionally, by using this technique students will learn from each other. Many times, youths are more prone to hear out their peers over adults. Naturally, this caters to those thoughts and allows students to take in the needed knowledge, but in a way that is more entertaining. Working in groups also provides the teacher with many new lesson options to keep the classroom engaging and motivating.

\section{Pre-instruction activities}

Pre-instruction activities are generally effective because they provide an easy break-in to new information. Additionally, they provide the students with notes, or something to look back on to relate the new information with the old so that the concept is easier to grasp. For instance, a chart may compare new materials with old thus drawing a line between to the two that the student can follow. These activities also draw the student into the new concept to keep them motivated and interested in what is being taught.

The pre-instruction technique could be applied in the introduction of a new concept or idea; or it can be applied to the planning of a project or paper that will be written by the student. Additionally, the teacher can use this technique to give instructions or notes on a topic that the student will later research and/or develop alone.

From this technique, the learning outcome is that the students will acquire important information that will help during the new unit of study or planning of a project that will require a lot of independent work. This is optimal to create a means of providing information that the students can later apply to other work in that lesson or unit.

\section{Make them Publish}

One effective way of valuing students' work as well as providing a real incentive to them, is to plan for a range of ways to publish their writing. The institution is to help the students to publish their own publishing, might be it evaluates the ideas of and interests of fellow students. Following a whole college Inset on book publishing techniques, every class published their own shared book; one example being an anthology of short spooky stories being composed. Their stories may be mounted on handmade paper, accompanied with each student's art work with a dramatic paper cut out front cover. The effort the student put into his work is immense, and the result may stun the others. The anthology is certainly being enjoyed by parents and other pupils and the students' pride in their work is clear to see.

Publishing the content with humour makes employees including the teachers of the institution and the students enjoy it and it may lead them to learn English language. If the teachers make the publishing online over Internet, the students concentrate on their literacy skills. Literacy skills help students gain knowledge through reading as well as using media and technology. These skills also help students create knowledge through writing. When the students encouraged, they consume and produce information and it helps to gain new skills.

\section{Connect them with WEB}

World Wide Web is one of the major and useful resources to students, particularly who are not with English background, to practice English learning even at classroom and home. There are so many websites to make focus on listening, some on vocabulary, many others on Grammar and some with a range of different learning activities. www.easyworldofenglish.com is one of the attractive and user-friendly website including Grammar, Pronunciation, reading and listening practice and an interactive picture dictionary. www.manythings.org is a website includes matching quizzes, word games, word puzzles, proverbs, slang expressions, anagrams, a random-sentence generator and other computer-assisted language learning activities. www.englishleap.com is a site to improve spoken English. Most of these websites are also available with mobile. Students who possess smart phones can access these sites over their mobile phones. It is really fun to learn English, one of the beautiful languages of the universe.

\section{Conclusion}

English teaching is one of the attractive activities to teachers of English language who takes it as a pride to teach and one of the lucrative activities to students who interests in acquiring one of the world's famous languages. As it is the most populous country in the world, in India, the educational institutions should extend uttermost support to the teaching community and make the students to acquire English language though it is a second or other language to be acquired to the pupil who come from background of other language. Educational 
department of the sate as well central should also focus on the same to assist the educational institutions or organisations to the maximum extent with supportive programs.

\section{Bibliography}

[1]. Agnew, P. W., Kellerman, A. S. \& Meyer, J. (1996). Multimedia in the Classroom, Boston: Allyn and Bacon.

[2]. Tapscott, D. (1998). Growing Up Digital: The Rise of the Net Generation, New York: McGraw-Hill. 